\title{
Analysis of the correlation between different forms of access to water and cases of gastroenteritis hospitalization in the territory of Médio Piranhas, Paraíba State, Brazil
}

\section{Análise da correlação entre diferentes formas de acesso à água e os casos de internações por gastroenterite no território do Médio Piranhas-PB}

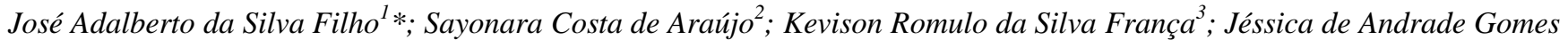 \\ Silva ${ }^{4}$; Virgínia de Fátima Bezerra Nogueira
}

\begin{abstract}
Drinking water has a direct influence on people's well-being, since this resource can transmit various diseases. This research proposes the diagnosis of access to water in the territory of Médio Piranhas, located in semiarid portion of Paraíba State, Brazil. The premise is based on the number of gastroenteritis hospitalization accounted for the Department of Health System Information. The authors selected the municipalities and collected secondary data from the Brazilian Institute of Geography and Statistics. The paper became evident the relationship between the form of access to water and the cases of gastroenteritis hospitalization. The results indicated that $71,75 \%$ of residences in the territory receive a water supply service. It was also observed 2.725 cases of gastroenteritis hospitalizations between 2010 and 2015, which provided a correlation of approximately $39 \%$, showing that more investments in infrastructure need to be made in order to improve the health and wellbeing of the population, and consequently reduce the chain of transmission of water-related diseases.
\end{abstract}

Key words: Alternative sources; semiarid; water-related diseases; water quality.

Resumo: A água de consumo exerce influência direta no bem-estar da população, uma vez que este recurso pode ser um veículo transmissor de diversas enfermidades. Esta pesquisa propõe o diagnóstico do acesso à água no território do Médio Piranhas, localizado no semiárido paraibano. A premissa encontra fundamento no grande número de internações por gastroenterite contabilizado pelo Departamento de Informática do Sistema Único de Saúde. Foram selecionados os municípios e coletados dados secundários do Instituto Brasileiro de Geografia e Estatística. O trabalho tornou notória a relação existente entre a forma de acesso à água e os casos de internação pela enfermidade adotada. Os resultados indicaram que $71,75 \%$ dos domicílios do território constam com uma cobertura por um sistema de tratamento e abastecimento de água. Foram contabilizados 2725 casos de internações por gastroenterite no período de 2010 a 2015, o que forneceu uma correlação de aproximadamente $39 \%$, evidenciando que mais investimentos em infraestrutura precisam ser feitos, visando melhorar a saúde e bem-estar da população, além de, consequentemente, reduzir a cadeia de transmissão das doenças de veiculação hídrica.

Palavras-chave: Fontes alternativas; semiárido; doenças de veiculação hídrica; qualidade da água.

\footnotetext{
*Autor para correspondência

Recebido para publicação em 27/08/2016; aprovado em 15/10/2016

${ }^{1}$ Environmental engineer; Federal University of Campina Grande; Pombal, Paraíba State, Brazil; E-mail: adalbertosilva15@gmail.com

${ }^{2}$ Environmental engineer; Federal University of Campina Grande; Pombal, Paraíba State, Brazil; E-mail: sayonara-vr@ hotmail.com

${ }^{3}$ Biologist; Federal University of Campina Grande; Patos, Paraíba State, Brazil; E-mail: kevsfranca@ gmail.com

${ }^{4}$ Biomedic; Federal University of Pernambuco; Recife, Pernambuco State, Brazil; E-mail: jessica.andrade.gs@gmail.com

${ }^{5}$ Professor; Federal University of Campina Grande; Pombal, Paraíba State, Brazil; E-mail: vbnogueira@ ccta.ufcg.edu.br
} 


\section{INTRODUCION}

The water has become a major global concern regarding the use, availability and quality. The supply of this resource is one of the basic sanitation services, as defined by Law $\mathrm{n}$. $11.445 / 2007$. It is constituted by activities, infrastructure and installations to public drinking water supply, from capture to building connections and their measuring instruments (BRASIL, 2007).

Although it is a right guaranteed by law, many localities are not included with this service. While others have irregularities in the distribution system.

According to Daniel and Cabral (2011), the discontinuity in water supply is not an isolated problem, being observed in several Brazilian cities, and it is attributed to the lack of systems to meet demand. Another difficulty is to ensure access to water far from urban centers and rural areas.

Despite its importance to human life, the consumption of water can cause diseases due to the presence of bacteria, virus, protozoa and worms, which may induce pathological effects in men and animals (NASCIMENTO and BARBOSA, 2005).

These agents found in contaminated water are responsible for high rates of hospitalizations for diarrhea, enteritis and epidemic diseases, which are sources of morbidity and often have lethal results (WHO, 1996).

It is estimated that more than five million people die annually due to diseases associated with the consumption of contaminated water and inadequate sanitation. Approximately $88 \%$ of patients who die worldwide are conected with waterrelated diseases (WHO, 2011).

Among these diseases, we can mention the gastroenteritis. This term has been used for various pathological conditions of the gastrointestinal tract, whose main symptom is diarrhea, which may or may not be associated with nausea, vomiting and abdominal pain (CARVALHO et al., 2014). According to the mortality indicators of Brazil, there were 3.449 deaths related to diarrhea and gastroenteritis of presumed infectious origin in 2011 (MINISTÉRIO DA SAÚDE, 2013).

Gastroenteritis is closely linked to the consumption of contaminated water, lack of hygiene and inefficient sanitation services. The basic premise for establishing water quality is to promote the well-being and health of those who receive the service. There is a relationship between access to safe water, adequate sanitation infrastructure and human health (PHILIPPI JÚNIOR, 2005).

The issue shows the need for investments in infrastructure, as the population remains vulnerable and tends to search water in alternative sources, which often do not have adequate quality (SILVA FILHO et al., 2015).

Barreto, Pedreira and Will (2015) reported that the impact of environmental pollution on the occurrence of infectious diseases in community is difficult to measure, which has attracted the attention of the scientific community about mechanisms to correlate the potential for contamination and quality of drinking water.

In Brazil, the Ordinance n. 2914/2011 of the Ministry of Health provides for the procedures of control and water quality monitoring for human consumption and its potability standards (BRAZIL, 2011). It sets limits of parameters for the main physical, chemical and biological characteristics of water, which will provide increased security, in terms of quality, for the people who receive this service (SILVA FILHO et al., 2015; SILVA FILHO, ARAÚJO and NOGUEIRA, 2016).

Thus, the diagnosis of water supply situation is necessary to ascertain the real situation and coverage of this service. Scientific research on this subject in the semiarid portion of Paraíba State are scarce. The papers of Silva Filho et al. (2015); Silva Filho, Farias and Araújo (2015); Silva Filho, Araújo and Nogueira (2016); and Araújo et al. (2016) are the most relevant.

This study aims at diagnosing the water supply situation and analyzing the relation between the access to water from alternative sources and the cases of hospitalization due to gastroenteritis in a territory located in the semiarid of Paraíba State, Brazil.

\section{MATERIAL AND METHODS}

\section{Description of the study area}

The territory of Médio Piranhas, Paraíba State, Brazil, presents the following municipalities: Belém do Brejo do Cruz, Bom Sucesso, Brejo do Cruz, Brejo dos Santos, Cajazeirinhas, Catolé do Rocha, Jericó, Lagoa, Mato Grosso, Paulista, Pombal, Riacho dos Cavalos, São Bentinho, São Bento, São Domingos and São José do Brejo do Cruz. Through Table 1, we can check the total population and the area of each municipality and, in Figure 1, the geographic location of this territory.

Table 1. Population and area of the municipalities corresponding to the territory of Médio Piranhas, Paraíba State, Brazil.

\begin{tabular}{|lll}
\hline Municipality & $\begin{array}{l}\text { Population } \\
(\mathbf{2 0 1 0})\end{array}$ & $\begin{array}{l}\text { Area } \\
\left(\mathbf{K m}^{2}\right)\end{array}$ \\
\hline Belém do Brejo do Cruz & 7143 & 603,043 \\
\hline Bom Sucesso & 5035 & 184,102 \\
\hline Brejo do Cruz & 13123 & 398,921 \\
\hline Brejo dos Santos & 6198 & 93,846 \\
\hline Cajazeirinhas & 3033 & 287,894 \\
\hline Catolé do Rocha & 28759 & 552,112 \\
\hline Jericó & 7538 & 179,311 \\
\hline Lagoa & 4681 & 177,902 \\
\hline Mato Grosso & 2702 & 83,522 \\
\hline Paulista & 11788 & 576,9 \\
\hline Pombal & 32110 & 888,807 \\
\hline Riacho dos Cavalos & 8314 & 264,025 \\
\hline São Bentinho & 4138 & 195,965 \\
\hline São Bento & 30879 & 248,2 \\
\hline São Domingos & 2855 & 169,105 \\
\hline São José do Brejo do & 1684 & 253,019 \\
\hline Cruz & & \\
\hline Source: IBE (2010) & & \\
\hline
\end{tabular}

Source: IBGE (2010). 
Figure 1. Geographical location of the territory of Médio Piranhas, Paraíba State, Brazil.

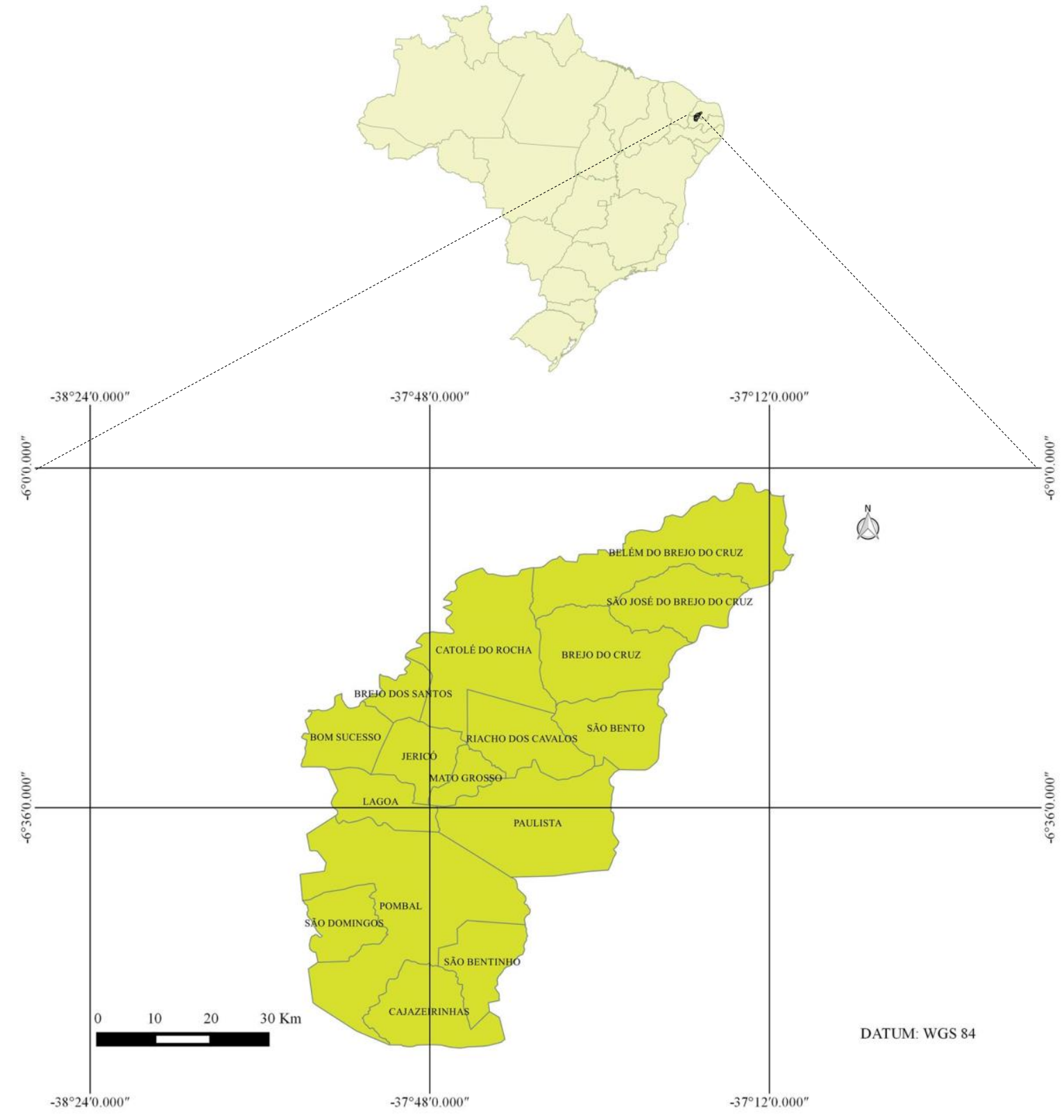

Source: Authors (2016).

\section{Procedures}

The methodology used in this study was based on the following steps:

(1) Secondary data analysis from the Brazilian Institute of Geography and Statistics 2010 Census (IBGE, 2010), about the water supply situation in the study area, as well as the different forms of access to water in residential level;

(2) Secondary data research from the Department of Health System Information (DATASUS, 2015), about the cases of hospitalizations for gastroenteritis in each municipality of the study area;

(3) Tabulation and spatial analysis using QGIS 2.6.0, which is a software used for mapping and geo-referencing of informations and images;

(4) Calculation of the correlation coefficient between the number of residences that are not supplied by the water supply system and the cases of hospitalization due to gastroenteritis in each municipality of the territory of Médio Piranhas, Paraíba State, Brazil, according to Equation (1):

$$
r=\frac{\left[\sum x y-\frac{\sum x \sum y}{n}\right]}{\sqrt{\left[\sum x^{2}-\frac{\left(\sum x\right)^{2}}{n}\right] \times\left[\sum y^{2}-\frac{\left(\sum y\right)^{2}}{n}\right]}}
$$

in which $\mathrm{x}$ is the number of residences that are not supplied by the water supply system; $y$ is the number of hospitalization for gastroenteritis and $\mathrm{n}$ is the number of municipalities in the territory.

\section{RESULTS AND DISCUSSION}

It was recorded by the Brazilian Institute of Geography and Statistics 2010 Census a total of 47.816 residences in the 
territory of Médio Piranhas, Paraíba State, Brazil. Also treatment and distribution water system is shown in Figure 2. according to the Institute, the access to water, through a

Figure 2. Coverage of water supply in the study area according to the Brazilian Institute of Geography and Statistics.

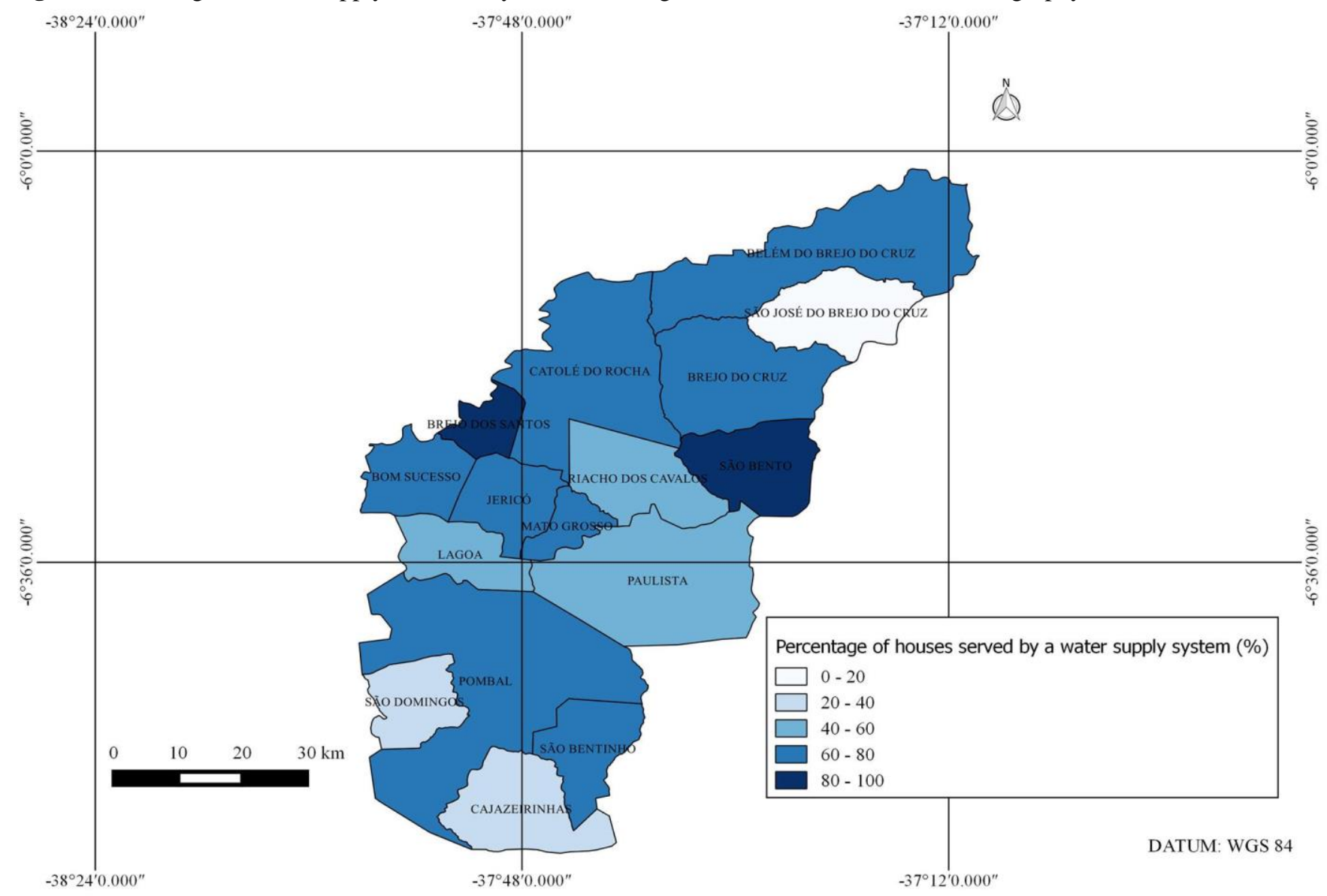

Source: Authors (2016)

Through the mapping of data concerning the number of residences served by public water supply in the study area, it is clear that the shades in dark blue are the highest percentages of access. And for the lighter blue shades, we can see the opposite.

São Bento and Brejo dos Santos present the highest coverage of the analyzed service, with rates of 84,14 and $80,94 \%$. Pombal is the municipality that presents the largest number of inhabitants in the territory, and features $79,35 \%$ of supply coverage, which is not considered efficient, since a little more than $20 \%$ of residences are not supplied by water supply system. The municipality that has the lowest number of inhabitants, São José do Brejo do Cruz, it is also the one that has the worst situation, since none of the households are supplied.

The situation is also critical in other municipalities, as Cajazeirinhas, Paulista, Riacho dos Cavalos and São Domingos, which less than half of residences receive this sanitation service. Throughout the territory, we see the lack of equity of access to this service.

However, the residences that do not have this service, have access to water through other means, which were recorded by IBGE, as show in Figure 3.
Figure 3. Forms of access to water in the territory of Médio Piranhas, Paraíba State, Brazil, according to the Brazilian Institute of Geography and Statistics 2010 Census.

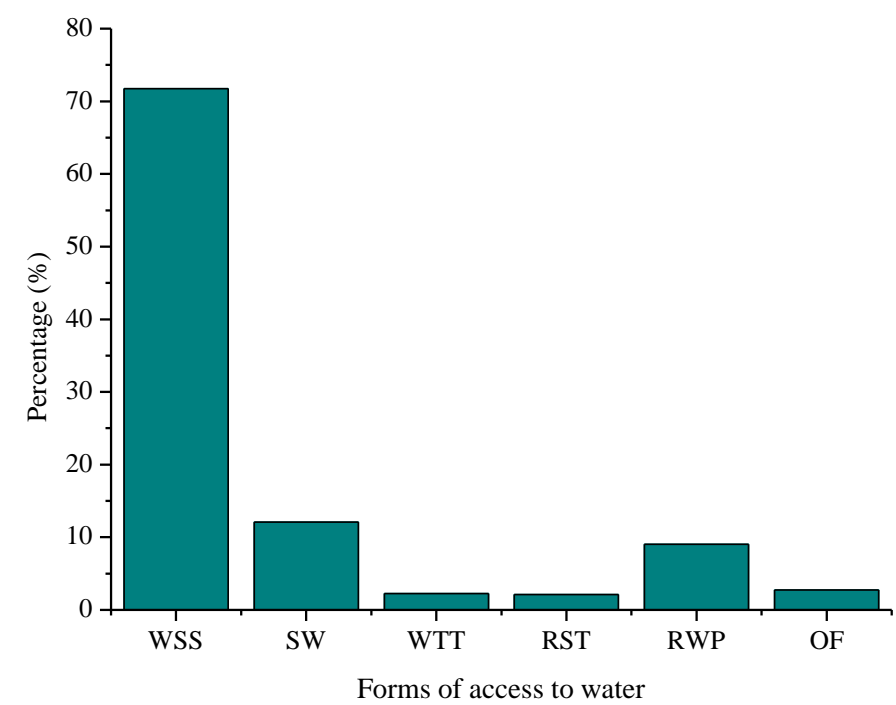

Legend: WSS - Water supply system; SW - springs and wells; WTT: Water tank truck; RST - Rainwater stored in cisterns; RWP - River, weir, pond; OF - Other forms.

Source: IBGE (2010).

Through the analysis of Figure 3, we can observe that $71,75 \%$ of the total of residences in the territory have access 
to water for water supply system. While 12,$10 ; 2,26 ; 2,09$; 9,03 ; and $2,76 \%$ use this resource from springs and wells; water tank truck; rainwater stored in cisterns; river, weir, pond; or other forms, respectively. Therefore, these plots are vulnerable because they are supplied by a non-potable source or a source of dubious origin.

According to Silva Filho et al. (2015), who conducted a study in the same territory, the areas that had more coverage for water supply system are almost in its entirety in urban zones. And the diffuse rural population of the region in question, in most cases, does not present or have an inefficient coverage.

The percentage of residences that use rainwater stored in tanks can be greater than was accounted for by the Brazilian Institute of Geography and Statistics 2010 Census. In Paraíba State, many rural families have been benefited from the construction of tanks by the Training and Mobilization Program for Coexistence with the semiarid: One Million Rural Cisterns. However, the management of water accumulated may not occur properly, affecting the water quality before reaching the final consumer (SILVA et al., 2006).

It should also be noted that the semiarid region has irregular rainfall rates. Thus, a large part of cisterns are supplied by water tank trucks, which results in a greater concern in terms of quality, being a potential source of contamination by the lack of quality, as well as the manner in which the resource is transported. (SARMENTO et al., 2012).

Water consumption through alternative sources is considered unsafe due to the ignorance of its physical, chemical and biological attributes. Another relevant factor is that relates to improper handling of these sources, for example, the use of any dirty container or improper storage, and the lack of equipment maintenance. Thus, the vulnerability to situations that cause disease becomes broad due to these contaminations (SILVA FILHO, MORAIS and SILVA, 2013).

In Figure 4, we can observe the cases of hospitalization for gastroenteritis from the official statistics provided by the Department of Health System Information.

Figure 4. Distribution of gastroenteritis hospitalization in the territory of Médio Piranhas, Paraíba State, Brazil, between 2010 and 2015.

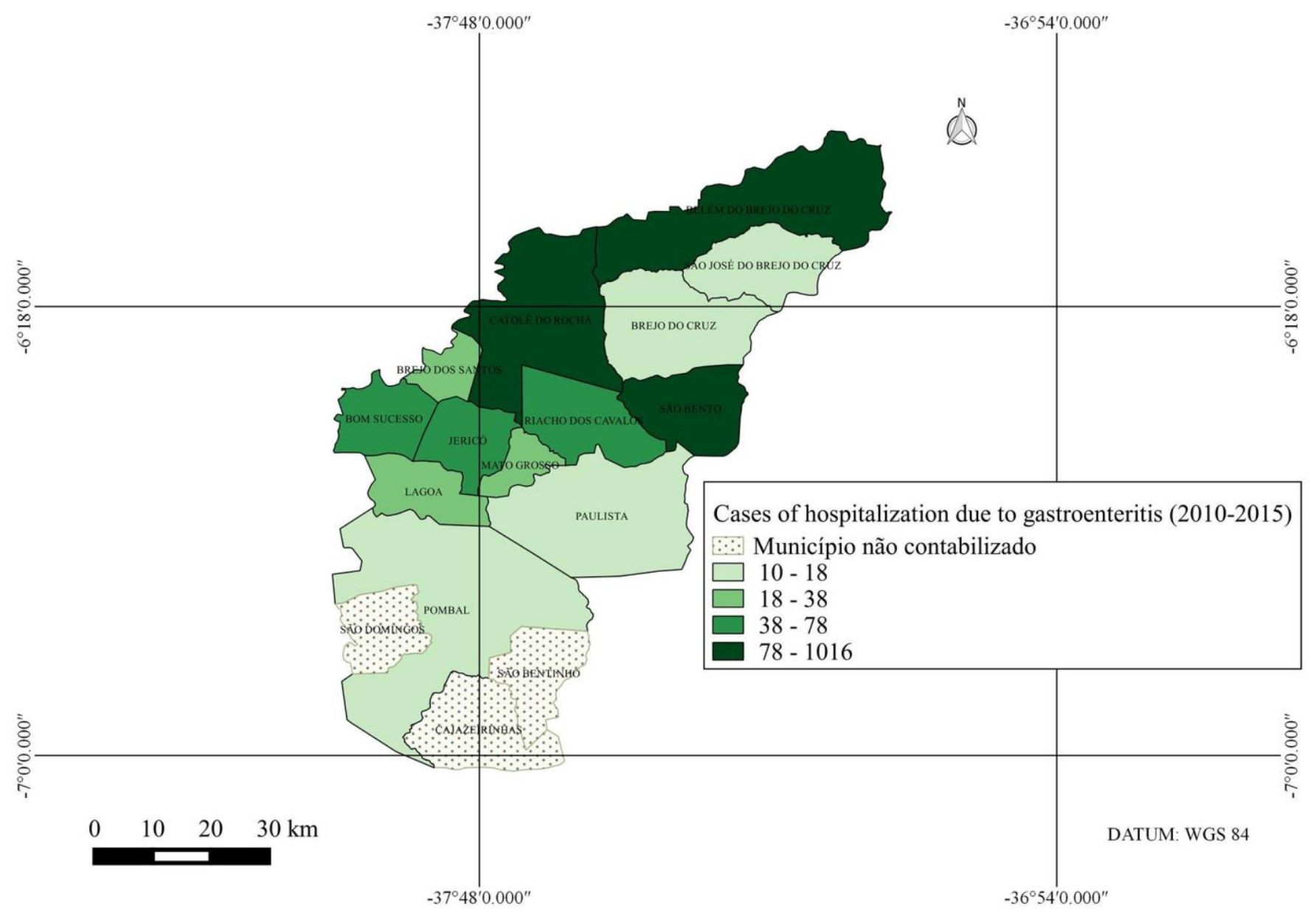

Source: Authors (2016).

Based on the figure above, we can infer about one of the most morbidities associated with water-related diseases, gastroenteritis. The municipalities of Belém do Brejo do Cruz, Catolé do Rocha and São Bento achieved the highest case reports of hospitalizations for gastroenteritis. These numbers contradict the percentage of water supply system, which has values of 71,$31 ; 76,46$; and $84,14 \%$. Thus, these values indicate that the water disinfection system of the treatment station may even be efficient, but during the course of this resource to the distribution network may exist points that contaminate the water, for example, by a faulty pipe.

Another important issue is the preservation of waters quality during the period of their stay in reservoirs. In general, the population is not aware of the need for maintenance, 
cleaning and sanitizing of reservoirs and facilities. A considerable problem is the use of water as a supplement with other sources, which increases the risk of contamination.

A low notification registered in the municipalities of Pombal, Paulista and Brejo do Cruz, linked to low supply coverage values, 79,35; 49,00; and 72,94\%, respectively, suggested small levels of investment in health. Cajazeirinhas, São Bento and São Domingos do not have data available in DATASUS.

The correlation coefficient (Eq. 1), between the number of residences that are not served by a water supply system and the number of hospitalizations for gastroenteritis, gave a value of 0,39 . Thus, the number of residences that are not supplied by this sanitation service explain statistically in approximately $39 \%$ the cases hospitalization for gastroenteritis in the territory. According to Cohen (1988), this obtained value is regarded as an almost moderate correlation.

The article 30 of the Federal Constitution (BRASIL, 1988) gives the obligation of the municipalities to manage and provide, directly or by concession or permission, the local interest. It is responsible of municipal management the right to ensure sanitation services, not excluding the State and Federal levels (D'AGUILA et al., 2000).

\section{CONCLUSION}

The diagnosis of water supply has proven to be an important information to be discussed with the social actors of the territory of Médio Piranhas. It was noticed by the results that the cover of access to water by a water supply system is not enough in the region. It is necessary governmental action to speed up works relating to environmental sanitation and to improve the quality of life of this population.

Through research, it became apparent that water quality directly affects the health of consumers. The authors found a positive correlation of approximately $39 \%$ between the number of residences that are not supplied by water supply system and the cases of hospitalization due to gastroenteritis. This value was not higher because of the absence of data on DATASUS in three municipalities, the high variability of residences and population among the territory, the precariousness of notifications and the lack of water supply.

We can also conclude that even in municipalities that had excellent coverage by water supply system, cases of gastroenteritis hospitalization are significant, indicating possible flaws in the residences packaging or in the distribution network.

\section{ACKNOWLEDGMENTS}

The authors gratefully acknowledge the Department of Health System Information from Brazil and the Brazilian Institute of Geography and Statistics for providing the data for this research.

\section{REFERENCES}

ARAÚJO, S. C.; SIlva FILHO, J. A.; SIlvA, G. M. S.; ANDRADE SOBRINHO, L. G.; NOGUEIRA, V. F. B. Espacialização dos serviços básicos de saneamento na zona rural do município de Pombal-PB. Revista Verde de
Agroecologia e Desenvolvimento Sustentável, v. 11, n. 3, p. 122-130, 2016.

BARRETO, R. L.; PEDREIRA, M. M.; WILL, R. M. M. M. Monitoramento da qualidade da água para consumo humano no estado da Bahia no ano 2014. Revista Baiana de Saúde Pública, v. 39, n. 1, p. 31-40, 2015.

BRASIL. Constituição Federal. Constituição da República Federativa do Brasil: promulgada em 5 de outubro de 1988. Contêm as emendas constitucionais posteriores. Brasília, DF: Senado, 1988.

BRASIL. Lei n. 11.445, de 5 de janeiro de 2007. Estabelece diretrizes nacionais para o saneamento básico. Brasília, 2007, $17 \mathrm{p}$.

BRASIL. Ministério da Saúde. Secretaria de Vigilância em Saúde. Portaria n. 2.914 do Ministério da Saúde. Estabelece os procedimentos e responsabilidades relativos ao controle e vigilância da qualidade da água para consumo humano e seu padrão de potabilidade. Diário Oficial [da] União, Brasília, DF, 12 dez. de 2011.

CARVALHO, T. C. N; GABBAY, Y. B.; SIQUEIRA, J. A. M.; LINHARES, A. C.; PARENTE, A. T. Conhecimento sobre gastroenterite viral pelos professionais de saúde de um hospital materno-infantil de referência no estado do Pará, Brasil. Revista Pan-Amazônica de Saúde, v. 5, p. 11-18, 2014.

COHEN, Jacob. Statistical power analysis for the behavioral sciences. Hillsdale, NJ, Erlbaum, 1988.

D'AGUILA, P. S.; ROQUE, O. C. C.; FERREIRA, A. P.; RAMOS, A. M. U.; MIRANDA, C. A. S. Avaliação da Qualidade de Água para Abastecimento Público. Cadernos de Saúde Pública, Rio de Janeiro-RJ, v. 16, n. 3, p. 791-798, 2000.

DANIEL, M. H. B.; CABRAL, A. R. A. Vigilância da Qualidade da Água para Consumo Humano (Vigiagua) e os Objetivos do Desenvolvimento do Milênio (ODM). Caderno de Saúde Pública, v. 19, n. 4, p. 487-492, 2011.

DATASUS - DEPARTAMENTO DE INFORMÁTICA DO SISTEMA ÚNICO DE SAÚDE. Casos de internação por gastroenterite no período de 2010 a 2015. Disponível em: < http://www2.datasus.gov.br/DATASUS/index.php?area=02 >. Acesso em: $10 \mathrm{dez} 2015$.

IBGE - INSTITUTO BRASILEIRO DE GEOGRAFIA E ESTATÍSTICA. Cidades. 2010. Disponível em: <http://cidades.ibge.gov.br/xtras/perfil.php >. Acesso em: 10 $\operatorname{dez} 2015$.

MINISTÉRIO DA SAÚDE. Departamento de Informática do SUS. Sistema de Informação de Mortalidade. Mortalidade Brasil: óbito por residência, por capítulo CID 10, segundo região. Brasília: Ministério da Saúde, 2013.

NASCIMENTO, S. A. M.; BARBOSA, J. S. F. Qualidade da água do aquífero freático no Alto Cristalino de Salvador, 
bacia do Rio Lucaia, Salvador, Bahia. Revista Brasileira de Geociências, v. 35, n. 4, p. 543-550, 2005

PHILIPPI JÚNIOR, A. Saneamento, Saúde e Ambiente. Barueri, SP: Manole, 2005. 842 p.

SARMENTO, E. B.; COELHO, L. F. O.; SILVA, L. C.; OLIVEIRA, A. M. B. M. Qualidade da água de cisternas rurais e sua segurança sanitária, caso do assentamento Jacú, município de Pombal-PB. In: Conferência Internacional em Gestão Ambiental Colaborativa- CIGAC,1., 2012, Sousa-PB. Anais... Sousa: MOTIRÕ, 2012. p. 1-6.

SILVA FILHO, A. P. C.; MORAIS, R. D.; SILVA, J. B. Doenças de veiculação hídrica: Dados epidemiológicos, condições de abastecimento e armazenamento da água em Massaranduba - PB. Geoambiente On-line, v. 20, n. 20, p. 8396, 2013.

SILVA FILHO, J. A.; ARAÚJO, S. C.; NOGUEIRA, V. F. B. Water supply diagnosis in the municipality of Cajazeiras, Paraíba State, Brazil. Revista Verde de Agroecologia e Desenvolvimento Sustentável, v. 11, n. 2, p. 11-15, 2016.

SILVA FILHO, J. A.; FARIAS, C. A. S.; ARAÚJO, S. C. Análise de grupos populacionais rurais vulneráveis as doenças de veiculação hídrica: um estudo de caso no semiárido paraibano. In: Workshop Internacional de Água no Semiárido Paraibano, 2., 2015, Campina Grande. Anais... Campina Grande: REALIZE, 2015. p. 1-6.

SILVA FILHO, J. A.; SALES, L. G. L.; ARAÚJO, S. C.; MARTINS, W. A. Diagnóstico do abastecimento de água para a região do Médio Piranhas no semiárido paraibano: Uma análise em nível de setor censitário do IBGE. In: Congresso Nacional de Meio Ambiente de Poços de Caldas, 12., 2015, Poços de Caldas. Anais... Poços de Caldas: IFSULDEMINAS, 2015. v. 7, 8 p.

SILVA, M. M. P.; OLIVEIRA, L. A.; DINIZ, C. R.; CEBALlOS, B. O. S. Educação ambiental para o uso sustentável de água de cisternas. Revista de biologia e ciências da Terra, v. 6, n. 1, p. 122 - 136, 2006.

WORLD HEALTH ORGANIZATION - WHO. Guidelines for drinking-water quality. 4. ed. Geneva, 2011.

WORLD HEALTH ORGANIZATION - WHO. Guidelinesfor Drinking-Water Quality. Geneva, 1996. 